\title{
Effect of metal buffer layers on the growth of GaN on Si substrates
}

\author{
Jun Hyeong Lee, Yeon Su Yu, Hyung Soo Ahn, Young Moon Yu* and Min Yang ${ }^{\dagger}$ \\ Department of Applied Sciences, Korea Maritime University, Busan 606-791, Korea \\ *Korea LED-Marine Convergence Technology R\&D Center, Pukyong National University, Busan 608-739, Korea \\ (Received July 18, 2013) \\ (Revised August 6, 2013) \\ (Accepted August 9, 2013)
}

Abstract AlN buffer layers have been used for the growth of GaN layers on Si substrates. However, the doping of high concentration of carriers into AlN layers is still not easy, therefore it may cause the increase of series resistance when it is used for the electrical or optical devices. In this work, to improve such a problem, the growth of $\mathrm{GaN}$ layers on $\mathrm{Si}$ substrates were performed using metal buffer layers instead of AlN buffer layer. We tried combinations of $\mathrm{Ti}, \mathrm{Al}, \mathrm{Cr}$ and $\mathrm{Au}$ as metal buffer layers for the growth of $\mathrm{GaN}$ on $\mathrm{Si}$ substrates. Surface morphology was measured by optical microscope and scanning electron microscope (SEM), and optical properties and crystalline quality were measured by photoluminescence (PL) and X-ray diffractometer (XRD), respectively. Electrical resistances for both cases of AlN and metal buffer layer were compared by current-voltage (I-V) measurement.

Key words GaN, Buffer layer, AlN buffer layer, Si, Melt-back etching, Metal buffer layer, MOCVD

\section{실리콘 기판위에 금속 완충층을 이용한 $\mathrm{GaN}$ 성장과 특성분석}

이준형, 유연수, 안형수, 유영문*, 양민

한국해양대학교 응용과학과, 부산, 606-791

*부경대학교 LED 해양융합기술연구센터, 부산, 608-739

(2013년 7월 18일 접수)

(2013년 8월 6일 심사완료)

(2013년 8월 9일 게재확정)

요 약 실리콘 기판 위에 $\mathrm{GaN}$ 를 성장하기 위해서 $\mathrm{AlN}$ 완충층을 사용해 왔다. 그러나 AlN은 아직까지 high doping이 쉽지 않기 때문에, 이로 인해 $\mathrm{AlN}$ 를 전자소자나 광소자 제작을 위한 완충층으로 이용하는 경우 직렬 저항의 증가라는 문 제가 발생할 수 있다. 본 연구에서는 이러한 문제점을 개선하기 위해 AlN 완충층 대신에 금속 완충층을 사용하여 실리콘 기판 위에 $\mathrm{GaN}$ 박막 성장실험을 수행하였다. $\mathrm{Al}, \mathrm{Ti}, \mathrm{Cr}$ 그리고 $\mathrm{Au}$ 등을 금속 완충층으로 사용하여 실리콘 기판 위에 $\mathrm{GaN}$ 층을 성장하였다. 성장된 $\mathrm{GaN}$ 박막의 표면 특성을 분석하기 위해 광학현미경과 $\mathrm{SEM}$ 을 사용하였고, 결정성과 광학적 특성 을 평가하기 위하여 PL과 XRD 분석을 실시하였으며 $\mathrm{AlN}$ 완충층을 사용한 경우와 금속 완충층을 사용한 경우의 저항 차 이를 확인하기 위하여 전류-전압 특성을 측정하였다.

\section{1. 서 론}

실리콘 기판은 저렴한 가격, 높은 열전도도와 전기 전 도도 등 기존의 사파이어 기판에 비해 많은 이점을 가지 고 있다. 그러나 실리콘 기판 위에 $\mathrm{GaN}$ 를 MOCVD (metal organic chemical vapor deposition) 결정 성장 장치에 의해 결정성장하는 경우, $\mathrm{GaN}$ 와 실리콘 기판 사

\footnotetext{
Corresponding author

Tel: +82-51-410-4782

Fax: +82-51-404-3986

E-mail: myang@hanyang.ac.kr
}

이의 큰 격자상수 및 열팽창 계수 차이에 의하여 crack 이 발생하기 쉽고 또한, $\mathrm{Ga}$ 에 의한 melt-back etching 등 실리콘 기판 위에 III족 질화물 반도체 층을 성장하 는 데에는 많은 문제점들을 가지고 있다[1-4]. 하지만 $\mathrm{AlN}$ 을 실리콘 기판과 $\mathrm{GaN}$ 박막층 사이에 완충층으로 사용하기 시작하면서 응력의 완화 등을 통해 cracking과 결정결함을 상당 수준 낮출 수 있음이 보고되어 왔다[57]. 또한, 고온에서 성장시킨 $\mathrm{AlN}$ 완충층은 MOCVD 방 법으로 결정성장할 때 $\mathrm{Ga}$ 에 의한 실리콘 기판의 meltback etching을 막아주는 것으로 확인되어 왔다 $[8,9]$. 그러나 아직까지 $\mathrm{AlN}$ 층을 고농도의 자유캐리어를 가지 
도록 doping하는 것은 쉽지 않은 상황이어서 AlN 완충 층을 사용하는 경우 제작된 소자의 전기적 저항을 증가 시킬 수도 있다는 문제점이 있다. 또한, 실리콘 기판과 $\mathrm{GaN}$ 사이의 큰 격자상수 및 열팽창계수 차이의 극복을 위해 $\mathrm{AlN}$ 이 포함된 초격자 구조 또는 다층 완충층 구조 등이 사용되고 있는데 이들 다층 구조의 최적화를 위해 서는 매우 정밀한 성장 조건의 제어가 필요하며, $\mathrm{AlN}$ 층이 다층으로 사용되기 때문에 이 역시 제작된 소자의 동작 저항을 증가 시킬 수 있다는 문제점이 있다[10]. 그러므로 $\mathrm{AlN}$ 에 의한 전기적 저항을 감소시키면서 동시 에 고품질의 $\mathrm{GaN}$ 층을 실리콘 기판 위에 성장할 수 있 는 새로운 종류의 완충층에 대한 연구는 결정 성장에 관 한 학문적 의미와 더불어 전자소자 및 광소자에 대한 산 업적 의미로도 매우 중요하다고 할 수 있다. 본 연구에 서는 $\mathrm{AlN}$ 완충층의 단점을 보완할 수 있는 금속 완충층 을 이용하여, 결정 성장 시 발생하는 실리콘 기판의 melt-back etching 현상을 방지하고 실리콘 기판에 AlN 완충층을 사용할 때 생기는 문제점인 전기적 저항의 증 가 문제를 해결함과 동시에 실리콘 기판 위에 성장되는 $\mathrm{GaN}$ 의 결정성을 향상시키기 위한 금속 완충층의 종류와 결정 성장 조건에 대한 최적 조건을 확보하고자 한다. 금속 완충층은 전기적 전도성이 우수하고 금속 자체의 연성이 있어서, $\mathrm{AlN}$ 완충층을 사용하는 경우에 $\mathrm{AlN}$ 과 $\mathrm{GaN}$ 층 사이의 큰 격자상수 차이에 의해 발생하는 응력 의 감소효과도 기대할 수 있을 것으로 판단한다. 또한, 광전 집적회로(opto-electronic integrated circuit, OEIC) 는 실리콘 기판을 기반으로 하면서 전류인가를 위한 금 속층의 채용이 필수적이기 때문에 실리콘 기판위에서 금 속 완충층을 이용한 $\mathrm{GaN}$ 의 성장은 매우 중요한 의미를 가진다고 할 수 있다. $\mathrm{GaN}$ 결정은 c-축 방향과 다른 결 정 방향에 대해 확산 원자들의 포텐셜 장벽이 워낙 차이 가 커서 대개의 성장 조건에서 c-축 방향의 wurtzite 구 조로 성장되는 경향이 강하여 최근에는 비정질임에도 불 구하고 석영 또는 강화 유리 기판 위에 $\mathrm{GaN}$ 단결정을 성장시키려는 시도들이 이루어지고 있다[11]. 이와 마찬 가지로, 금속층 또한 대개의 성장 조건에서 비정질 또는 불완전한 단결정 구조를 가지기 쉬워서 이를 완충층으로 하여 그 위에 $\mathrm{GaN}$ 단결정을 성장시키는 것은 쉽지 않 은 일이지만, 단결정 성장을 위한 최적 성장 조건이 확 립된다면 금속 완충층의 장점을 여러 분야에서 소자 제 작에 활용할 수 있을 것으로 기대한다.

\section{2. 실험방법}

기판은 (111) 방향의 실리콘 기판을 사용하였다. 성장하 기 전에 기판은 아세톤과 메탄올로 각각 초음파 세척되었
Table 1

Type and thickness of the deposited metals

\begin{tabular}{lll}
\hline Sample number & Metal type & Thickness \\
\hline 1 & $\mathrm{Ti} / \mathrm{Al}$ & $10 \AA / 10 \AA$ \\
2 & $\mathrm{Al} / \mathrm{Ti}$ & $10 \AA / 10 \AA$ \\
3 & $\mathrm{Ti}$ & $20 \AA$ \\
4 & $\mathrm{Al}$ & $20 \AA$ \\
5 & $\mathrm{Au} / \mathrm{Al}$ & $10 \AA \mathrm{I} / 10 \AA$ \\
6 & $\mathrm{Ni} / \mathrm{Al}$ & $10 \AA / 10 \AA$ \\
7 & $\mathrm{Cr} / \mathrm{Ti}$ & $10 \AA / 10 \AA$ \\
\hline
\end{tabular}

으며, 유기세척 후 실리콘 기판 위의 산화막 제거를 위해 BOE(buffered oxide etchant) 용액을 이용하여 etching 한 후 곧 바로 e-beam evaporator의 챔버에 장착하여 금속 완충층을 증착하였다. 사용된 금속의 종류 및 증착 조건 은 Table 1에 요약하였다. 금속 증착이 완료된 후, 금속 완충층이 증착된 각 샘플을 $\mathrm{MOCVD}$ 장비의 반응관 안 에 장착하고 $1150^{\circ} \mathrm{C}$ 에서 $\mathrm{GaN}$ 층을 20 분간 성장하여 평 균 두께는 $1 \mu \mathrm{m}$ 정도가 되도록 하였다. 이때 $\mathrm{NH}_{3}$ 와 $\mathrm{N}_{2}$ 가스는 $500 \mathrm{sccm}$ 으로 하였고, TMG(trimethylgallium) source는 $10 \mathrm{cc}$ 로 흘려주었다. 분위기 가스 및 운반가스 로는 질소를 이용하였으며 반응관의 압력은 상압으로 하 였다. 성장이 종료된 $\mathrm{GaN}$ 박막의 표면특성을 관찰하기 위해 광학 현미경과 $\mathrm{SEM}$ 을 사용하였고, $\mathrm{GaN}$ 박막의 결정 배향을 관찰하기 위해 XRD 측정을 실시하였다. $\mathrm{PL}$ 측정을 통하여 실리콘 기판위에 성장된 $\mathrm{GaN}$ 의 광 학적 특성을 분석 하였다. 한편, AlN 완충층과 금속 완 충층을 각각 사용한 경우의 전기적 저항 특성을 평가하 기 위하여 $\mathrm{GaN}$ 표면과 실리콘 기판 표면에 전극 형성 을 실시하여 전류-전압 측정을 실시하였다. $\mathrm{GaN}$ 표면에 는 접촉저항에 의한 오차를 줄이기 위해 $0.8 \mathrm{~mm}^{2}$ 의 비 교적 넓은 면적을 가지는 패턴에 $\mathrm{Ti} / \mathrm{Au}(200 / 1000 \AA)$ 을 증착하였으며 실리콘 기판 표면에는 패턴 없이 $\mathrm{Ti} / \mathrm{Al}$ $(200 / 1000 \AA)$ 을 전면 증착하였다.

\section{3. 결과 및 고찰}

다양한 결정 성장 조건에 의해 실리콘 기판 위에 $\mathrm{GaN}$ 를 성장하기 전에, 우선적으로 실리콘 기판의 melt-back etching을 막을 수 있는 금속 완충층의 조합을 확인하였 다. Fig. 1에는 금속 완충층을 사용하여 성장한 $\mathrm{GaN}$ 박 막의 표면을 광학 현미경으로 관찰한 모습을 보였다. Fig. 1(a)는 Ni/Al 금속 완충층을 사용하여 성장한 $\mathrm{GaN}$ 박막에 대한 표면이고 Fig. 1(b)는 Ti/Al 금속 버퍼층을 사용하여 성장한 $\mathrm{GaN}$ 박막에 대한 표면이다. 실리콘 기 판위에 양질의 $\mathrm{GaN}$ 을 성장시키기 위해서는 성장 중 $\mathrm{Ga}$ droplet과 화학적 반응에 의한 실리콘 기판의 melt-back 

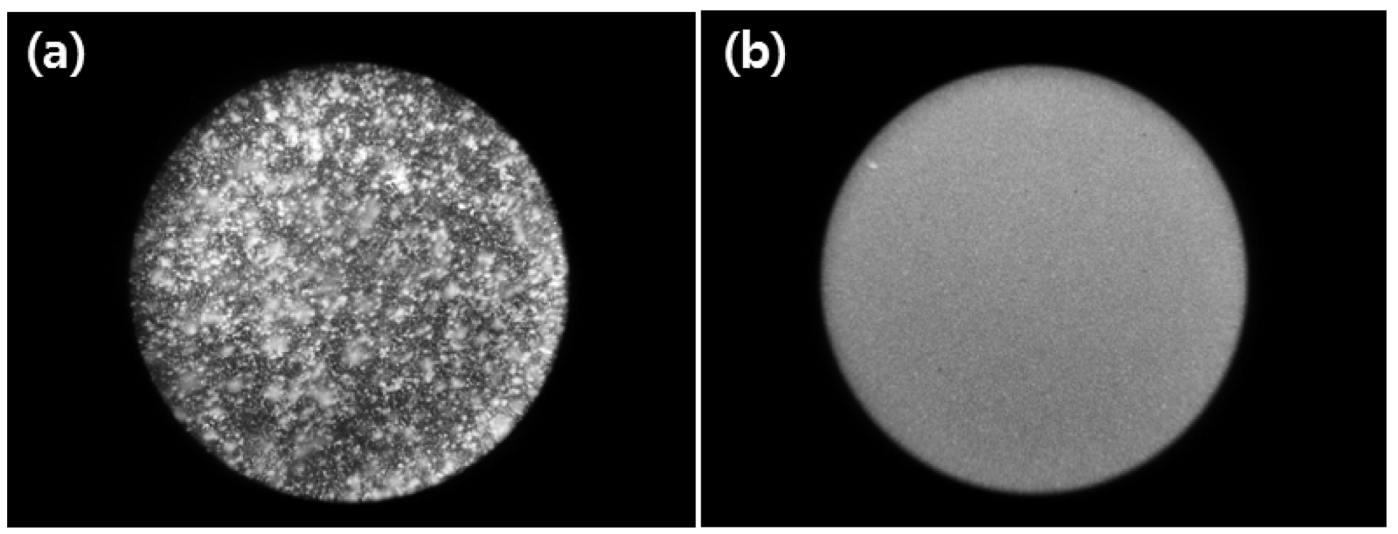

Fig. 1. Optical microscopy images of GaN layers with metal buffer layers of (a) Ni/Al and (b) Ti/Al.

etching을 막는 것이 매우 중요하다. $\mathrm{Ni} / \mathrm{Al}$ 을 완충층으로 사용한 경우에는 Fig. 1(a)에 보인 바와 같이 $\mathrm{Ga}$ 에 의한 실리콘 기판의 melt-back etching에 의하여 기판 표면이 거칠고 실리콘 기판이 etching 되어 검게 보이는 부분이 많이 있음을 알 수 있다. 사진으로 보이진 않았지만 $\mathrm{Ni}$ / $\mathrm{Al}$ 뿐만 아니라 $\mathrm{Au} / \mathrm{Al}, \mathrm{Cr} / \mathrm{Ti}$ 완충층 또한 melt-back etching을 막지 못하는 것을 확인하였다. 반면에 $\mathrm{Ti} / \mathrm{Al}$ 완충층은 melt-back etching을 효과적으로 막고 있음을 확인할 수 있었다(Fig. 1(b)). 한편, Table 1에는 Ni/Al과 $\mathrm{Ti} / \mathrm{Al}$ 으로 구성된 금속 완충층들의 조합 이외에도 $\mathrm{Ti}$, $\mathrm{Al}, \mathrm{Au} / \mathrm{Al}$ 그리고 $\mathrm{Cr} / \mathrm{Ti}$ 등의 금속 조합에 대한 조건들 을 제시하였으나 동일한 성장 조건에 대해서 모두 meltback etching 현상이 발생하여 본 연구에서 사용한 금속 조합들 중에서는 $\mathrm{Ti} / \mathrm{Al}$ 의 금속 조합만 melt-back etching 을 방지할 수 있는 금속 완충층으로 사용할 수 있음을 확인하였다. Ti/Al 금속층이 melt-back etching을 막을 수 있었던 것은 다른 금속 종류들에 비해서 결정 성장에 사용되는 여러 종류의 화학물질에 대해 반응성이 비교적 낮고, 결정 성장 온도에서 원자간 배열이 재배치되는 과
정에서 보다 더 치밀한 구조로 형성되었기 때문인 것으 로 판단된다. 물론, $\mathrm{Ni} / \mathrm{Al}$ 의 경우 및 다른 금속 조합의 경우에도 적절한 결정 성장 조건 아래에서는 melt-back etching을 방지할 수 있는 조건들이 있을 수도 있으나 앞에서 언급한 결정 성장 조건은 실리콘 기판 위에 고온 $\mathrm{GaN}$ 반도체 층을 성장하는 일반적인 조건이기 때문에 본 연구에서는 이후 진행되는 결정 성장에서 실리콘 기 판 위에 최적화된 $\mathrm{GaN}$ 박막을 성장하기 위해 실리콘 기판이 etching되지 않는 $\mathrm{Ti} / \mathrm{Al}$ 금속을 완충층으로 사용 하여 $\mathrm{GaN}$ 박막을 성장하였다.

$\mathrm{GaN}$ 의 성장 조건은 $\mathrm{TMG}, \mathrm{NH}_{3}$, carrier $\mathrm{N}_{2}$ gas의 유 량을 각각 $2 \mathrm{sccm}, 500 \mathrm{sccm}, 500 \mathrm{sccm}$ 으로 하였으며 성장온도는 $1150^{\circ} \mathrm{C}$ 로 하였다. 성장된 $\mathrm{GaN}$ 의 표면 특성 을 Fig. 2(a)에 나타내었다. Fig. 2(a)에서 볼 수 있듯이 성장된 $\mathrm{GaN}$ 는 2차원 박막으로 성장되지 않고 3차원적 인 다결정 형태로 성장되었다. 이러한 문제점을 해결하 기 위해서 $\mathrm{GaN}$ 를 성장하기 전에 암모니아 가스 없이 $\mathrm{Ga}$ 원자들만 기판 표면에 분포될 수 있도록 $\mathrm{TMG}$ 원료 만 흘려주는 TMG pre-flow 공정을 실시하였다. TMG

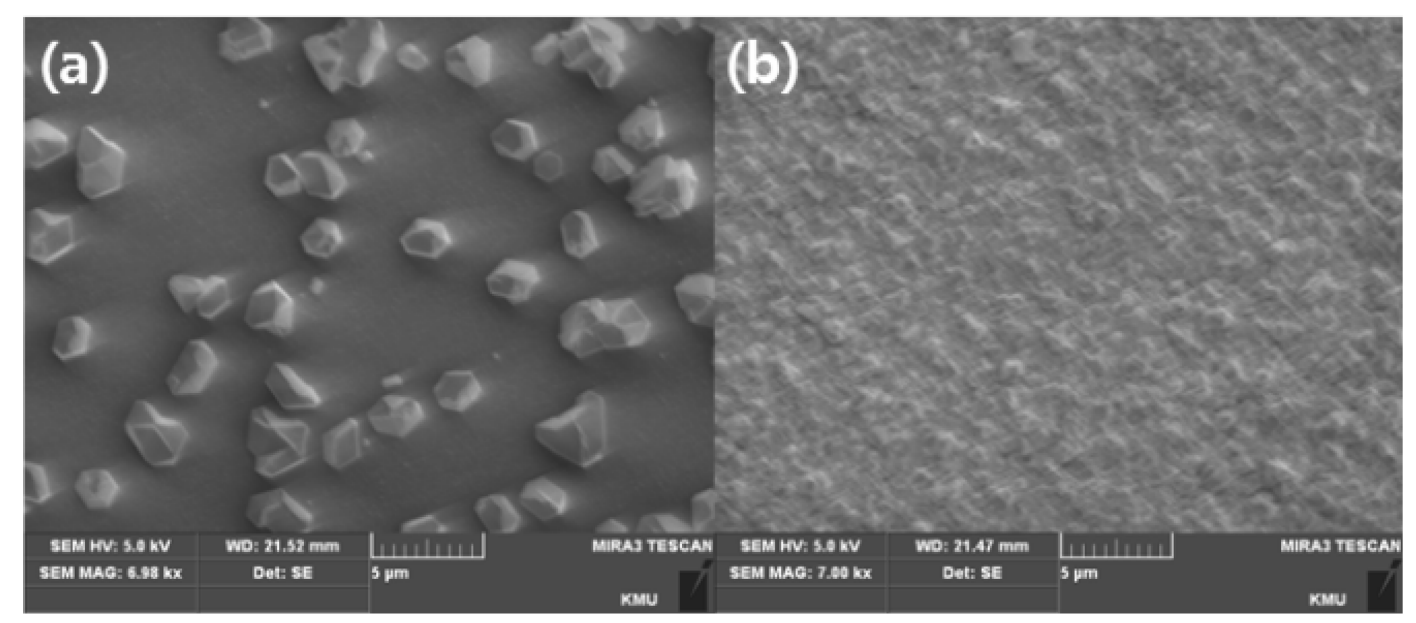

Fig. 2. SEM images of GaN layers with metal buffer layers (a) without TMG pre-flow (b) with TMG pre-flow. 


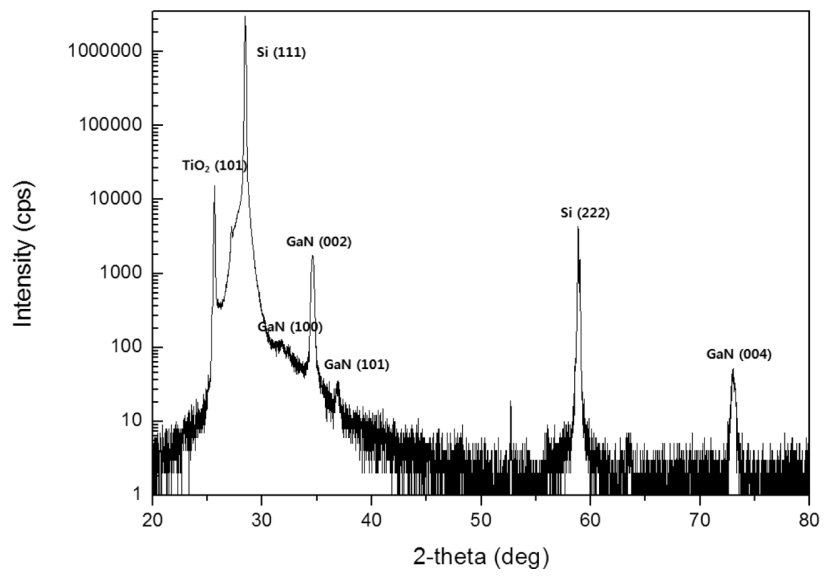

Fig. 3. X-ray diffraction pattern of GaN layer with metal buffer layer.

pre-flow 공정은 TMG 유량은 $2 \mathrm{sccm}$, 지속시간은 2 분 그리고 온도는 $700^{\circ} \mathrm{C}$ 에서 실시하였다. $\mathrm{TMG}$ pre-flow 공정을 실시한 경우의 결정 성장 결과를 Fig. 2(b)에 보 였다. TMG pre-flow 공정을 이용한 GaN는 Fig. 2(a)의 직접 $\mathrm{GaN}$ 를 성장 시킨 것에 비하여 매우 향상된 표면 특성을 보이고 있다. 따라서 TMG pre-flow 공정에 의 해 실리콘 기판 위에 $\mathrm{GaN}$ 성장을 위한 핵 입자들이 고 르게 생성될 수 있음을 확인할 수 있었다.

TMG pre-flow 공정을 실시하는 방법으로 금속 완충 층 위에 성장된 $\mathrm{GaN}$ 박막의 $\mathrm{X}$-선 회절 분석 결과를 Fig. 3에 나타내었다. Fig. 3에서 볼 수 있듯이 금속 완 충층 위에 성장한 $\mathrm{GaN}$ 박막에서 $32^{\circ}, 34^{\circ}, 36^{\circ}$ 그리고 $72^{\circ}$ 에서 $\mathrm{GaN}$ (100), (002), (101), (004)에 해당하는 피 크가 관찰되었고, $27^{\circ}$ 에서 $\mathrm{TiO}_{2}$ (101)에 해당하는 피크 가 관찰되었다. 그리고 $28^{\circ}, 58^{\circ}$ 에서 실리콘 (111), (222) 에 해당하는 피크가 관찰 되었다. 비록 완전한 단결정이 아니지만 각 결정면들에 의한 peak들의 크기를 비교하 여 보았을 때 주로 (002) 방향으로 배향된 형태로 결정 성장이 되었음을 확인할 수 있었다.

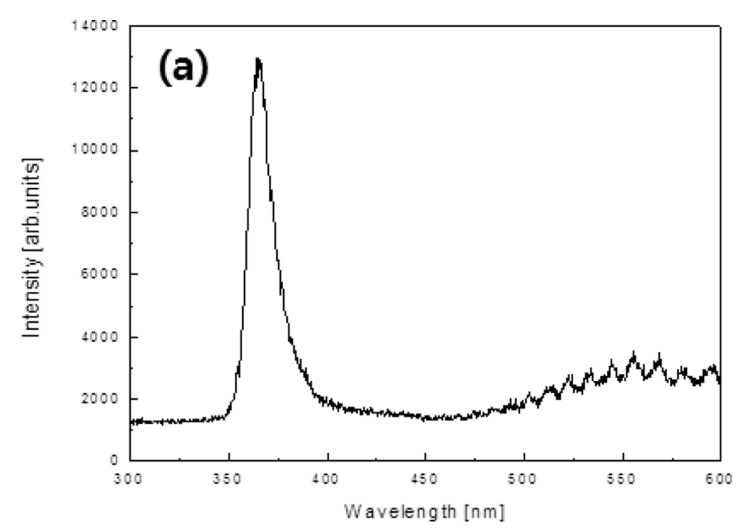

Fig. 4(a)는 금속 완충층을 사용하여 $\mathrm{GaN}$ 박막을 성장 한 샘플이고 Fig. 4(b)는 $\mathrm{AlN}$ 완충층을 사용하여 $\mathrm{GaN}$ 박막을 성장한 샘플의 상온에서의 각각의 $\mathrm{PL}$ 스펙트럼이 다. 두 샘플의 $\mathrm{GaN}$ 박막은 동시에 성장이 이루어졌으며 성장된 $\mathrm{GaN}$ 두께는 약 $1 \mu \mathrm{m}$ 이다. 각각의 $\mathrm{PL}$ 스펙트럼 에서 피크파장은 $365 \mathrm{~nm}$ 에서 나타나며 각각의 $\mathrm{FWHM}$ 는 $15 \mathrm{~nm}, 12 \mathrm{~nm}$ 로 큰 차이가 나타나지 않는 것을 확인할 수 있었다. 금속 완충층을 사용하여 $\mathrm{GaN}$ 박막을 성장한 경우의 FWHM 값이 약간 크게 나타난 것은 완전한 단 결정이 아닌 상태에서 서로 다른 결정 방향을 가지는 결정립들의 경계에서 의도하지 않은 불순물들의 유입이 있었던 것에 그 원인이 있을 것으로 추측된다. 또한, 금 속 완충층을 사용한 경우 500 600 nm에 걸쳐 yellowluminescence가 관찰되고 있는데 일반적으로 yellowluminescence의 원인에 대해서는 여러 가지 연구결과들 이 발표되어 왔지만[12] 본 실험결과에 의한 경우에는 불완전한 단결정성에 의한 물질의 결정 결함 또는 결정 결함에 의한 불순물 유입에 의한 것으로 판단된다.

전기적 저항 특성을 분석하기 위해서 $\mathrm{AlN}$ 완충층을 사용한 샘플과 금속 완충층을 사용한 샘플의 $\mathrm{GaN}$ 표면 과 실리콘 기판 표면에 각각 전극을 형성한 후 $\mathrm{I}-\mathrm{V}$ 특 성을 측정하여 그 결과를 Fig. 5에 나타내었다. Fig 5(a) 는 금속 완충층을 사용하여 $\mathrm{GaN}$ 박막을 성장한 샘플이 고 Fig. 5(b)는 AlN 완충층을 사용하여 $\mathrm{GaN}$ 박막을 성 장한 샘플의 측정 결과이다. 직렬저항(동작전압: $\sim 10 \mathrm{~V}$ ) 을 측정한 결과, $\mathrm{AlN}$ 완충층을 사용한 $\mathrm{GaN}$ 박막의 경 우는 $5825 \Omega$, 금속 완충층을 사용한 $\mathrm{GaN}$ 박막의 경우 는 $1100 \Omega$ 으로 약 5 배 이상 개선되었음을 확인할 수 있 었다. 물론, 본 연구에서는 $\mathrm{AlN}$ 층에 인위적으로 도핑을 실시하지는 않았지만, 금속을 실리콘 기판 위에 $\mathrm{GaN}$ 층 을 성장시키기 위한 완충층으로 사용하는 경우, 고농도 도핑이 쉽지 않은 $\mathrm{AlN}$ 층을 사용하는 경우에 비해서 소 자의 동작 저항을 어느 정도 개선할 수 있게 될 것으로 기대된다.

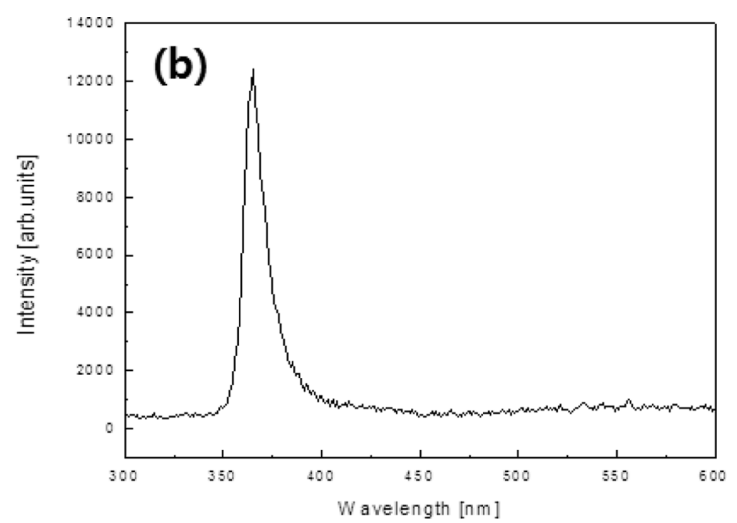

Fig. 4. PL spectra of GaN layers with (a) metal buffer layer and with (b) AlN buffer layer. 

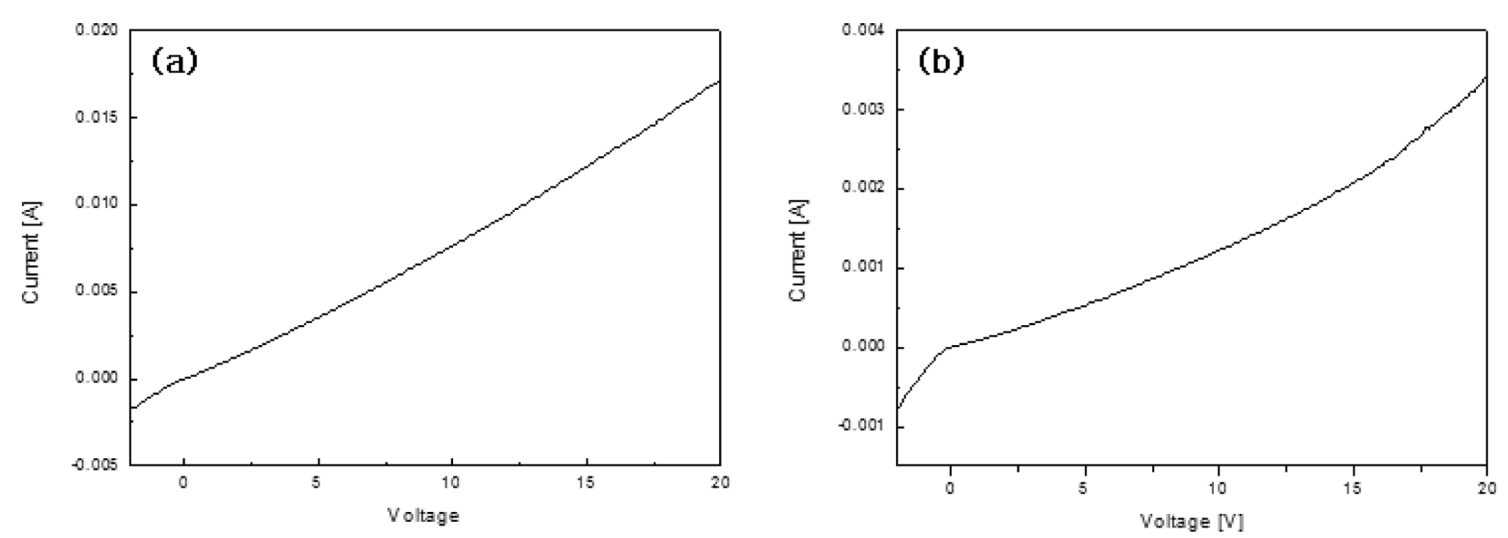

Fig. 5. I-V characteristics of GaN layers with (a) metal buffer layer and with (b) AlN buffer layer.

\section{4. 결 론}

금속 완충층을 사용하여 실리콘 기판 위에 $\mathrm{GaN}$ 박막 성장실험을 수행하였다. 각각의 금속 종류에 따라 금속 완충층의 최적의 조건을 조사하였으며 melt-back etching 을 방지할 수 있는 경우는 $\mathrm{Ti}$ 과 $\mathrm{Al}$ 을 금속 완충층으로 사용하였을 때이다. 금속 완충층을 사용하는 경우, $\mathrm{TMG}$ pre-flow 공정 같은 표면 전처리 과정이 $\mathrm{GaN}$ 결정 성장 에 매우 큰 영향을 주는 것을 확인하였다. 비록 완전한 단결정은 아니지만 대부분의 결정방향이 (002)면으로 배 향되며 성장되는 것을 확인할 수 있었고 광학적 특성도 $\mathrm{AlN}$ 을 완충층으로 사용한 경우에 비하여 크게 나빠지지 는 않는 것으로 확인되었다. 금속 완충층을 사용한 $\mathrm{GaN}$ 박막은 $\mathrm{AlN}$ 완충층을 사용한 $\mathrm{GaN}$ 박막 보다 동일한 동작 전압에서 전기적 저항도 개선되었다는 것을 확인할 수 있었다. 앞으로 완충층 및 결정 성장 조건의 최적화 를 통해서 단결정 성장 조건을 확보한다면, 본 연구의 결과들은 실리콘 기판을 이용하여 $\mathrm{GaN}$ 층 또는 그 밖 의 질화물 반도체를 성장하는 경우, 전자소자 및 광소자 그리고 광전 집적소자의 제작에 다양한 접근 방법으로 이용될 수 있을 것으로 생각한다.

\section{감사의 글}

본 연구는 지식경제부 산업원천기술개발사업(과제번호: 10037416 , 해양 LED 융합기술지원 기반구축 및 상용화 기술개발)으로 지원된 연구임.

\section{참 고 문 헌}

[ 1 ] X. Weng, S. Raghavan, J.D. Acord, A. Jain, E.C. Dickey and J.M. Redwing, "Evolution of threading dislocations in MOCVD-grown GaN films on (111) Si substrates", J. Crystal Growth 300 (2007) 822.

[2] D.K. Kim and C.B. Park, "Growth of crack-free GaN films on $\mathrm{Si}(111)$ substrates with AlN buffer layers", J. Kor. Phys. Soc. 49 (2006) 1497.

[ 3 ] A. Dadgar, P. Veit, F. Schulze, J. Blasing, A. Krtschil, H. Witte, A. Diez, T. Hempel, J. Christen, R. Clos and A. Krost, "MOVPE growth of $\mathrm{GaN}$ on $\mathrm{Si}$ - substrates and strain", Thin Solid Films 515 (2007) 4356.

[ 4 ] Z. Liu, X. Wang, J. Wang, G. Hu, L. Guo, J. Li, J. Li and Y. Zeng, "Effects of buffer layers on the stress and morphology of GaN epilayer grown on Si substrate by MOCVD”, J. Crystal Growth 298 (2007) 281.

[ 5 ] V.N. Bessolov, V. Yu. Davydov, Yu. V. Zhilyaev, E.V. Konenkova, G.N. Mosina, S.D. Raevskii, S.N. Rodin, Sh. Sharofidinov, M.P. Shcheglov, H.S. Park and M. Koike, "GaN films grown by vapor-phase epitaxy in a hydride chloride system on $\mathrm{Si}(111)$ substrates with AlN buffer sublayers", Techn. Phys. 31(11) (2005) 915.

[6] J.X. Zhang, Y. Qu, Y.Z. Chen, A. Uddin, P. Chen and S.J. Chua, "Structural and photoluminescence study of thin GaN film grown on silicon substrate by metalorganic chemical vapor deposition", Thin Solid Films 515 (2007) 4397.

[ 7 ] Y. Dikme, G. Gerstenbrandt, A. Alam, H. Kalisch, A. Szymakowski, M. Fieger, R.H. Jansen and M. Heuken, "Investigation of buffer growth temperatures for MOVPE of GaN on Si(111)", J. Crystal Growth 248 (2003) 578.

[ 8 ] C.K. Shu, J. Ou, H.C. Lin, W.K. Chen and M.C. Lee, "Isoelectronic In-doping effect in $\mathrm{GaN}$ films grown by metalorganic chemical vapor deposition", Appl. Phys. Lett. 73 (1998) 641.

[9] K.Y. Zang, S.J. Chua, L.S. Wang, C.V. Thompson, "Evolution of AlN buffer layers on silicon and effects on the properties of epitaxial GaN films", Phys. Status Solidi C7 (2003) 2067.

[10] A. Watanabe, T. Takeuchi, K. Hirosawa, H. Amano, K. Hiramatsu and I. Akasaki, "The growth of single crystalline $\mathrm{GaN}$ on a $\mathrm{Si}$ substrate using $\mathrm{AIN}$ as an intermediate layer", J. Crystal Growth 128 (1993) 391.

[11] J.H. Choi, Z. Andrei, S.I. Kim, C.W. Baik, M.H. Yang, S.S. Park, H. Suh, U.J. Kim, S.H. Bin, J.S. Lee, M. 
Kim, J.M. Kim and K. Kim, "Nearly single-crystalline $\mathrm{GaN}$ light-emitting diodes on amorphous glass substrates", Nature Photonics 5 (2011) 763.

[12] H. Xu, X. Hu, X. Xu, Y. Shen, S. Qu, C. Wang and S.
$\mathrm{Li}$, "Gallium vacancies related yellow luminescence in N-face GaN epitaxial film”, Applied Surface Science 258 (2012) 6451. 